\title{
A randomized trial analyzing the effects of primary versus delayed primary closure of incision on wound healing in patients with hollow viscus perforation
}

\author{
Aditya Baksi (D), Shamita Chatterjee (D), Udipta Ray ${ }^{3}$ (D), Nilima Nilima ${ }^{4}$ (D), Washim Firoz Khan ${ }^{1}$ (D), Niladri Banerjee ${ }^{1}$ (DD \\ ${ }^{1}$ Department of Surgical Disciplines, All India Institute of Medical Sciences, New Delhi, India \\ 2 Department of Surgery, Nil Ratan Sircar Medical College and Hospital, Kolkata, India \\ ${ }^{3}$ Department of General Surgery, Medica Super Speciality Hospital, Kolkata, India \\ ${ }^{4}$ Department of Biostatistics, All India Institute of Medical Sciences, New Delhi, India
}

\begin{abstract}
Objective: Delayed primary closure (DPC) of the skin has been suggested to decrease superficial surgical site infection (SSSI) in patients undergoing surgery for peritonitis secondary to hollow viscus perforation, but there is no consensus. The aim of this study was to compare the outcomes of primary closure (PC) and DPC of the skin in terms of SSSI, fascial dehiscence and length of hospital stay (LOS).

Material and Methods: Sixty patients, undergoing emergency surgery for perforation peritonitis, were randomized to PC $(n=30)$ and DPC ( $n=30)$. Patients in the DPC group underwent skin closure four or more days after surgery when the wound was clinically considered appropriate for closure. Patients in the PC group had skin closure at the time of surgery.

Results: Incidence of SSSI was significantly less in the DPC group (7.4\%) compared to the PC $(42.9 \%)(p=0.004)$. However, the median time of DPC was the $10^{\text {th }} \mathrm{POD}$, i.e., these wounds required considerable time to become clinically suitable for closure. Incidence of fascial dehiscence was comparable between the two groups $(p=0.67)$. Length of hospital stay (LOS) was 13.8 days in the DPC group compared to 13.5 days in PC; the difference was not significant $(p=$ 0.825).
\end{abstract}

Conclusion: DPC of the skin incision resulted in the reduction of SSSI. However, this did not translate into a reduction in hospital stay, as it took considerable time for these wounds to become appropriate for DPC, thus bringing into question any real advantage of DPC over PC.

Keywords: Viscus perforation, surgical site infection, peritonitis, wound infection, delayed primary closure

Cite this article as: Baksi A, Chatterjee S, Ray U, Nilima N, Khan WF, Banerjee N. A randomized trial analyzing the effects of primary versus delayed primary closure of incision on wound healing in patients with hollow viscus perforation. Turk J Surg 2020; 36 (4): 327-332

\section{Corresponding Author}

Aditya Baksi

E-mail: aditya.baksi@gmail.com

Received: 08.09.2020

Accepted: 02.12 .2020

Available Online Date: 29.12 .2020

(C) Copyright 2020 by Turkish Surgical Society Available online at www.turkjsurg.com

DOI: $10.47717 /$ turkjsurg.2020.4882

\section{INTRODUCTION}

Surgical site infection (SSI) is one of the commonest complications of surgery, which increases morbidity, length of hospital stay (LOS) and treatment expenses, posing a significant financial burden to patients and society. Increase in LOS results in decreased availability of beds, thus, further straining an already resource-constrained health care system. The method of skin closure - primary or delayed primary - has been implicated as an important factor in the development of post-operative SSI in contaminated and dirty wounds. However, there is no consensus among surgeons as to which is a better technique, and treatment decisions are often based on personal preference. Most randomized trials comparing primary closure (PC) and delayed primary closure (DPC) have been found to be at high risk of bias. The aim of this randomized study was to compare the outcomes of primary and DPC, in terms of superficial SSI (SSSI), fascial dehiscence and length of hospital stay (LOS), in patients undergoing emergency surgery for peritonitis secondary to hollow viscus perforation.

\section{MATERIAL and METHODS}

A randomized parallel group trial was conducted at Medical College Kolkata, a tertiary referral center in eastern India, from January 2012 to September 2013. The study was approved by the Institutional Ethics Committee and registered with the Clinical Trials Registry - India (CTRI/2018/02/011973). Patients aged 12-65 years, 
who underwent emergency surgical intervention for perforation peritonitis, diagnosed clinically with radiological evidence, were included in the trial. Informed written consent was taken from all participants or their legal guardians (for patients aged $<18$ years). Immunocompromised patients and patients with diabetes mellitus, chronic kidney disease, severe obesity, pre-existing skin infection and malignant hollow viscus perforation were excluded from the study. After a decision for emergency laparotomy was made, patients were invited to participate in the trial. Patients who refused were excluded and underwent primary closure of the skin, which was our standard practice before the beginning of the trial. Generation of random allocation sequence was done by an independent statistician using computer generated randomization tables in 1:1 ratio and sequentially numbered, sealed, opaque envelopes to ensure concealed allocation. Eligible participants were randomly assigned to one of the two groups, DPC and PC, by the principal investigator. No blinding techniques were applied.

Demographic and clinical data were recorded in a pre-structured proforma. All patients were resuscitated prior to surgery. Intravenous antibiotics (ceftriaxone-sulbactam $1.5 \mathrm{~g}$ and metronidazole $500 \mathrm{mg}$ ) were administered pre-operatively at the time of resuscitation and continued at least 48 hours post-operatively. Intravenous amikacin was also added if renal function was adequate. Antibiotics were upgraded depending on the clinical response of the patient, degree of contamination, concomitant infective conditions and culture report of subsequently sent wound swab.

Surgery was performed by final year residents under supervision of a senior surgeon. Midline laparotomy was done for all patients except for those who were clinically diagnosed to have localized appendicular perforation, for which, a grid-iron incision was used. After source control, thorough peritoneal lavage was done with tepid normal saline till the effluent was clear. Drains were placed at the discretion of the supervising surgeon. Fascial closure was done with no. 1 polypropylene (for midline incisions) and no. 1 polyglactin (for grid-iron incisions). After fascial closure, the anaesthetist was asked to open the sealed envelopes, and the patients were randomized to one of the two groups.

In the PC group, the skin was closed immediately with 2-0 polyamide black interrupted sutures without any subcutaneous sutures, and occlusive dressing with dry gauze was done. On post-operative day (POD) 2, the dressing was removed, and the wound was examined by one of the two senior surgeons in the team (SC or UR). If the wound was healthy, no further dressing was applied.

In the DPC group, interrupted sutures of the same material were placed but kept loose, with a knot at the end of long sutures, to prevent them from getting dislodged. Saline-soaked gauze was placed on the wound, followed by dry gauze and occlu- sive dressing. On POD 2, the dressing was removed, the wound examined, and the dressing changed with aseptic precaution. Twice daily dressing with saline-soaked gauze was continued till POD 4, when the wound was re-examined. In the absence of any sign of possible infection (serous or purulent discharge, flakes, necrosed or unhealthy granulation tissue), the skin was closed by tying knots on the pre-placed sutures. However, in the presence of any of the above signs, closure was deferred and twice daily dressing continued till the wound was healthy.

In both groups, stitch removal was done after ten days of skin closure. In both groups, if there were signs of SSI (purulent discharge, signs of inflammation), one or more stitches were removed, wound swab sent for culture and dressing continued, and the wound was allowed to heal by granulation. Patients were followed up at least for a month after skin closure.

\section{Outcomes}

Primary outcome was incidence of SSSI, defined as per the Centers for Disease Control and Prevention Guidelines 1999 (1). In both groups, SSSI was considered as the infection of the wound after skin closure. In the DPC group, any infection when the wound was kept open was not considered as SSSI. Secondary outcomes were incidence of fascial dehiscence, defined as a breach in the deep fascia of abdomen, and LOS, defined as total number of days from admission to discharge, including any readmission.

The sample size was calculated based on a study by Cohn et al. (2), in which the authors found $48 \%$ wound infection in patients with PC as opposed to only $12 \%$ in patients with DPC. In order to detect the specified difference, a sample size of 24 patients per group was obtained at $80 \%$ power and $95 \%$ confidence level for a two-sided test of significance. The calculation was done using nMasterv.1.0 software by the Department of Biostatistics, Christian Medical College, Vellore, India. Considering a dropout rate of $20 \%$ and rounding off to the nearest multiple of 10 , a target of 30 patients in each group was set.

Intention to treat analysis was done using the EZR plugin of $\mathrm{R}$ console. Quantitative variables were presented as mean \pm standard deviation (SD) along with range. Qualitative variables were summarized using frequency (percentages). Chi squared test or Fisher's exact test was used to investigate associations, if any, wherever applicable. Independent samples t test was used to compare a quantitative variable across DPC and PC groups. A modified intention to treat ( $\mathrm{mITT}$ ) and per protocol analysis were used. P value $<0.05$ was considered significant throughout.

\section{RESULTS}

Out of the 84 patients undergoing surgery for perforation peritonitis, 24 were excluded for various reasons. Sixty patients were randomly allocated to DPC $(n=30)$ and PC $(n=30)$. One patient in the DPC group and two in the PC group died within 72 hours 
of surgery, while two in the DPC group had protocol violation, thus, leaving 27 and 28 patients in the two groups, respectively, for final analysis (Figure 1).

Mean age of the patients was 37.6 \pm 14 years (range 13-76 years). Majority of the patients were males ( $n=51,85 \%)$. Eighteen patients (30\%) had appendicular perforation, of whom, five had midline laparotomy in view of generalized peritonitis, while the remaining 13 had grid-iron incision. Overall, 21.7\% had a grid-iron incision and $78.3 \%$ had midline incisions. Baseline demographic and clinical parameters were evenly distributed between the two groups (Table 1). Median time to skin closure in the DPC group was POD 10. Time to wound closure was 10 days in nine patients, 11 days in six patients and 12 days in three patients. Notably, DPC on POD 4, as planned, was possible in only five patients.

\section{Protocol deviation}

In two patients in the DPC group, the wound was not deemed suitable for closure; the pre-placed sutures were removed, and saline dressing was continued, and the wounds allowed to heal by granulation. They were excluded in the per protocol analysis (DPC, $n=27$ ) but included in mITT (DPC, $n=29)$ (Table 2).

\section{Superficial SSI (SSSI)}

In the PC group, 12 out of 28 patients (42.9\%) developed SSSI, necessitating opening of one or more sutures. Subsequently, these wounds were allowed to heal by secondary intention. Four of these 12 patients needed readmission. In the DPC group, only two patients (7.4\%) developed SSSI after skin closure. The difference in SSSI between the two groups was statistically significant ( $p=0.004$ ) in both mITT and per protocol analyses. The two patients, who had healing by granulation, were not considered to have SSSI as they never underwent any skin closure.

\section{Fascial dehiscence}

Three patients $(n=3,10.7 \%)$ in the PC group had fascial dehiscence. None of the patients in the DPC group developed fascial dehiscence after skin closure. The two patients in DPC group, who had protocol violation, also developed fascial dehiscence. The difference in incidence of fascial dehiscence was not significant on $\mathrm{mITT}(\mathrm{p}=0.67)$ or per protocol analysis $(p=0.236)$ (Table 2).

\section{Length of hospital stay}

Mean LOS was $13.8 \pm 4.2$ days in DPC group and $13.5 \pm 4.6$ days in $P C$ group ( $p=0.825$ ). The difference was not significant even on per protocol analysis $(p=0.64)$.

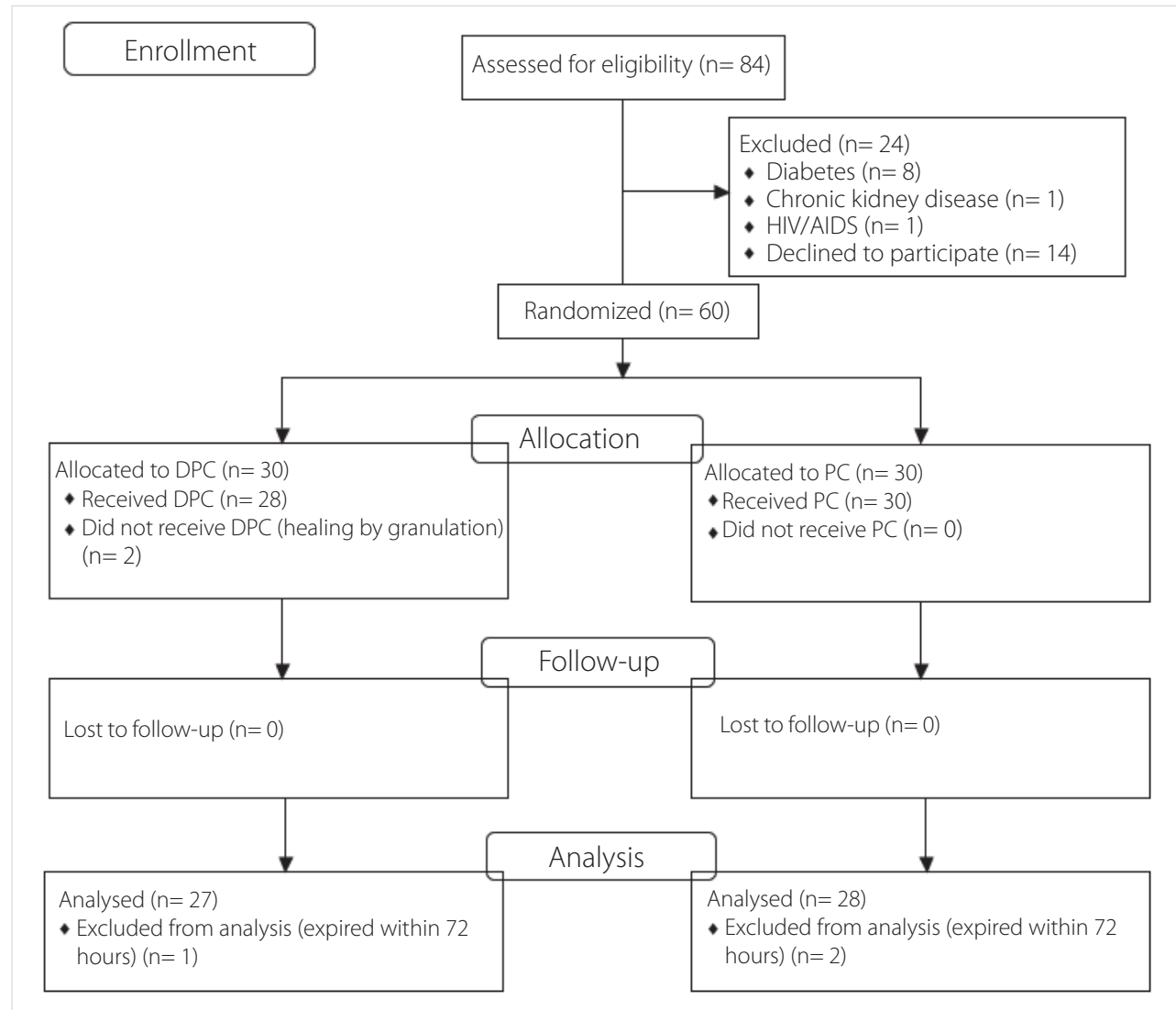

Figure 1. CONSORT flow diagram. 


\begin{tabular}{|c|c|c|c|}
\hline Characteristics & $\mathrm{DPC}(\mathrm{n}=30)$ & $P C(n=30)$ & $\mathrm{p}$ \\
\hline $\begin{array}{l}\text { Age in years } \\
\quad \text { Mean } \pm \text { SD (range) }\end{array}$ & $\begin{array}{c}37.2 \pm 13.6 \\
(13-76)\end{array}$ & $\begin{array}{c}38.1 \pm 14.7 \\
(16-75)\end{array}$ & 0.821 \\
\hline $\begin{array}{l}\text { Sex } \\
\qquad \begin{array}{l}\text { Male, } \mathrm{n}(\%) \\
\text { Female, n (\%) }\end{array}\end{array}$ & $\begin{array}{c}25(83.3) \\
5(16.7)\end{array}$ & $\begin{array}{c}26(86.7) \\
4(13.3)\end{array}$ & 0.999 \\
\hline $\begin{array}{l}\text { BMI in kg/m² } \\
\quad \text { Mean } \pm \text { SD (range) }\end{array}$ & $\begin{array}{c}24 \pm 3.5 \\
(17.1-32.3)\end{array}$ & $\begin{array}{c}24.5 \pm 3 \\
(18.2-33.2)\end{array}$ & 0.558 \\
\hline $\begin{array}{l}\text { ASA grade, } \mathrm{n}(\%) \\
\quad \leq 2 \\
\quad>2\end{array}$ & $\begin{array}{l}27(90) \\
3(10)\end{array}$ & $\begin{array}{l}26(86.7) \\
4(13.3)\end{array}$ & 0.999 \\
\hline $\begin{array}{l}\text { Duration of symptoms, } n(\%) \\
\quad \leq 6 \text { hours } \\
>6 \text { hours }\end{array}$ & $\begin{array}{c}1(3.3) \\
29(96.7)\end{array}$ & $\begin{array}{l}3(90) \\
27(10)\end{array}$ & 0.612 \\
\hline $\begin{array}{l}\text { Site of perforation, } \mathrm{n}(\%) \\
\text { Stomach/duodenum } \\
\text { Small bowel } \\
\text { Appendix } \\
\text { Large bowel }\end{array}$ & $\begin{array}{c}12(40) \\
8(26.7) \\
9(30) \\
1(3.3)\end{array}$ & $\begin{array}{c}11(36.7) \\
8(26.7) \\
9(30) \\
2(6.7)\end{array}$ & 0.999 \\
\hline $\begin{array}{l}\text { Procedure, } \mathrm{n}(\%) \\
\text { Graham patch repair } \\
\text { Appendicectomy } \\
\text { Resection anastomosis } \\
\text { Stoma } \\
\text { Primary repair }\end{array}$ & $\begin{array}{l}12(40) \\
9(30) \\
2(6.7) \\
6(20) \\
1(3.3)\end{array}$ & $\begin{array}{c}11(36.7) \\
9(30) \\
3(10) \\
7(23.3) \\
0(0)\end{array}$ & 0.999 \\
\hline $\begin{array}{l}\text { Total leucocyte count } \\
\text { Mean } \pm \text { SD (range) }\end{array}$ & $\begin{array}{l}10.870 \pm 3960 \\
(3500-19.200)\end{array}$ & $\begin{array}{l}12.006 \pm 6068 \\
(2000-28.500)\end{array}$ & 0.394 \\
\hline
\end{tabular}

Table 2. Modified intention to treat findings for SSSI, fascial dehiscence and LOS across the two skin closure procedures

\begin{tabular}{|c|c|c|c|c|}
\hline Outcome & DPC * & $\mathrm{PC}^{*}$ & Relative risk $(95 \% \mathrm{Cl})$ & $p$ \\
\hline SSSI, n (\%) & $2(7.4)$ & $12(42.9)$ & $0.17(0.04,0.70)$ & 0.004 \\
\hline Fascial dehiscence, n (\%) & $2(6.9)$ & $3(10.7)$ & $0.62(0.05,5.91)$ & 0.670 \\
\hline LOS in days, mean \pm SD (range) & $13.8 \pm 4.2(6,26)$ & $13.5 \pm 4.6(4,22)$ & $0.26(-2.06,2.58)$ & 0.825 \\
\hline
\end{tabular}

\section{DISCUSSION}

Surgical wounds in patients with secondary peritonitis are considered as "dirty" (class IV) wounds typically associated with a high rate of complications, including SSSI and fascial dehiscence. DPC was first widely used for soft tissue injuries of the extremities, especially compound fractures, during World War I and subsequently went on to be used in civilian practice (3). In one of the earliest comparative trials, Bernard and Cole have found a $42 \%$ incidence of SSI in patients undergoing primary closure of wounds compared to 8\% in DPC, done 24-72 hours after surgery (4). Grosfeld and Solit have found SSI rates of $34.1 \%$ and $2.3 \%$, respectively, in patients undergoing primary and DPC of appendectomy wounds, done on POD 5 (5). However, the results of prospective studies have been variable. In an RCT, Pettigrew has found no significant difference in wound infection between primary and DPC. Patients having DPC had greater LOS and did not accept the procedure well; at follow up, 19\% remembered it as an "intolerable" experience (6). Tsang et al. have studied 63 children with gangrenous or perforated appendicitis and found no difference in wound infection between the two groups. The wound was not closed in $24 \%$ of patients allocated to DPC because of significant exudate. For infected wounds, 
complete wound healing time (CWHT, defined as the time from surgery to complete apposition of wound edges with cessation of wound dressing) was greater in wounds closed primarily but the difference was not significant. However, for non-infected wounds, it was significantly higher for wounds that had DPC, thus, increasing patient discomfort, nursing requirement and LOS. The authors suggested that CWHT might be clinically more meaningful than incidence of SSI (7). In our study, although incidence of SSSI was significantly less in the DPC group, LOS was comparable. Prolonged hospital stay, despite a lower incidence of SSSI, can be explained by the fact that majority of the patients in DPC group had unhealthy wounds that were deemed inappropriate for closure and needed prolonged saline-gauze dressing. Most of these patients had to wait for $\geq 10$ days before their wounds could be closed, thus, negating the advantage of the decreased rate of wound infection after DPC. The decrease in incidence of SSSI due to DPC did not translate into a reduction in LOS. The perceived decrease in SSSI after DPC was only due to the way SSSI was defined in this study. In retrospect, we also feel that CWHT would be a more clinically relevant outcome in studies comparing primary versus DPC.

Some RCTs have found DPC to be advantageous in terms of incidence of wound infection. In a randomized trial on 51 patients, Cohn et al. have found a wound infection rate of $48 \%$ in patients having primary closure, compared to $21 \%$ in DPC. However, it is noteworthy that $46 \%$ of the patients allocated to DPC did not have DPC due to excessive discharge, and these wounds were allowed to heal by secondary intention. The difference in wound infection, though statistically significant, failed to result in any difference in LOS or hospital charges (2). Chiang et al., in a randomized trial of 70 patients, have found significantly lower wound infection and LOS in patients undergoing DPC. They performed DPC on POD 5 and did not mention if any wound was deemed unsuitable for closure (8). Duttaroy et al. have carried out DPC on POD 3 and found significantly lower SSI and LOS, compared to primary closure. Only $10.8 \%$ of patients allocated to DPC were considered unsuitable for closure on POD 3 (9). In our study, 83\% of patients did not have DPC on the scheduled day due to unhealthy appearance of the wound, which Duttaroy et al. have referred to as 'pre-DPC SSI'. Our decision was based on naked eye examination and was, to some extent, subjective. However, clinical examination was the only possible way to base this decision upon, as culture from wound swabs would take 48-72 hours for an objective assessment of the wound infection, and even that is not $100 \%$ accurate. Most of our patients were referred from district hospitals and presented 24 hours after onset of symptoms, which may explain the high rate of 'pre-DPC SSI'. A multicenter randomized trial from Thailand has reported lower SSI rates, albeit non-significant, with primary closure. LOS was comparable but treatment cost was significantly higher with DPC (10).
Rucinsky et al., in a meta-analysis of 2532 patients, have found no difference in SSSI between PC and DPC (11). Henry and Moss, in a meta-analysis of 6 RCTs, have found primary closure to be associated with less treatment failure, defined as purulent drainage requiring opening of wound (for $\mathrm{PC}$ ) or failure to close wound at scheduled time (for DPC) (12). A meta-analysis by Bhangu et al. has suggested that DPC may have a role in reducing SSI in contaminated and dirty abdominal incisions; however, there was lack of definitive evidence (13). Siribumrungwong et al., in a meta-analysis of 8 RCTs, have found no difference in SSI between PC and DPC, but hospital stay was significantly longer in patients with DPC (14). A recent meta-analysis of 12 RCTs by Tang et al. has concluded in the same lines as Bhangu et al., favouring DPC, with low-quality evidence (15).

Although several randomized trials have been conducted comparing PC and DPC, most of the studies are low quality as found in above meta-analyses. Our study is limited by a small sample size; however, it adds to the existing literature on this debate and emphasizes that there is no benefit of routinely performing DPC of dirty abdominal wounds. Future studies may be directed at patient reported outcomes like quality of life or long-term outcomes, for example incisional hernia, rather than incidence of wound infection, which, as seen in our study, may not be clinically relevant.

In conclusion, DPC of the skin in patients undergoing emergency surgery for perforation peritonitis is associated with a significant lower incidence of SSSI without any considerable decrease in LOS, as substantial time is required for the open wound to become appropriate for closure. The purported advantage of DPC, therefore, is questionable.

\section{ACKNOWLEDGMENT}

The authors would like to thank Dr. Ayan Jha, Department of Population and Family Health, Columbia Mailman School of Public Health, for his valuable contribution.

Ethics Committee Approval: The approval for this study was obtained from Medical College Kolkata Ethics Committee (Decision No: CTRI/2018/02/011973, Date: 17.12.2011)

Peer-review: Externally peer-reviewed.

Author Contributions: Concept - A.B., S.C., U.R.; Design - All of authors; Supervision - S.C., U.R.; Materials - All of authors; Data Collection and/or Processing - A.B., W.F.K., N.B.; Analysis and Interpretation - A.B., N.N.; Literature Review - All of authors; Writing Manuscript - A.B., S.C.; Critical Reviews - All of authors.

Conflict of Interest: The authors have no conflicts of interest to declare.

Financial Disclosure: The authors declared that this study has received no financial support. 


\section{REFERENCES}

1. Mangram AJ, Horan TC, Pearson ML, Silver LC, Jarvis WR. Guideline for prevention of surgical site infection. Centers for disease control and prevention (CDC) hospital infection control practices advisory committee. Am J Infect Control 1999; 27(2): 97-132; quiz: 133-4, discussion: 96. [CrossRef]

2. Cohn SM, Giannotti G, Ong AW, Esteban Varela J, Shatz DV, McKenney $M G$, et al. Prospective randomized trial of two wound management strategies for dirty abdominal wounds. Ann Surg 2001; 233(3): 409-13. [CrossRef]

3. Hepburn HH. Delayed primary suture of wounds. Br Med J 1919; 1(3033): 181-3. [CrossRef]

4. Bernard HR, Cole WR. Wound infections following potentially contaminated operations. Effect of delayed primary closure of the skin and subcutaneous tissue. JAMA 1963; 184: 290-2. [CrossRef]

5. Grosfeld JL, Solit RW. Prevention of wound infection in perforated appendicitis: experience with delayed primary wound closure. Ann Surg 1968; 168(5): 891-5. [CrossRef]

6. Pettigrew RA. Delayed primary wound closure in gangrenous and perforated appendicitis. BJS 1981; 68(9): 635-8. [CrossRef]

7. Tsang TM, Tam PKH, Saing H. Delayed primary wound closure using skin tapes for advanced appendicitis in children: A prospective, controlled study. Arch Surg 1992; 127(4): 451-3. [CrossRef]

8. Chiang R-A, Chen S-L, Tsai Y-C. Delayed primary closure versus primary closure for wound management in perforated appendicitis: A prospective randomized controlled trial. J Chin Med Assoc JCMA 2012 75(4): 156-9. [CrossRef]
9. Duttaroy DD, Jitendra J, Duttaroy B, Bansal U, Dhameja P, Patel G, et al. Management strategy for dirty abdominal incisions: primary or delayed primary closure? A randomized trial. Surg Infect 2009; 10(2): 129-36. [CrossRef]

10. Siribumrungwong B, Chantip A, Noorit P, Wilasrusmee C, Ungpinitpong $W$, Chotiya $P$, et al. Comparison of superficial surgical site infection between delayed primary versus primary wound closure in complicated appendicitis: a randomized controlled trial. Ann Surg 2018; 267(4): 631-7. [CrossRef]

11. Rucinski J, Fabian T, Panagopoulos G, Schein M, Wise L. Gangrenous and perforated appendicitis: a meta-analytic study of 2532 patients indicates that the incision should be closed primarily. Surgery 2000; 127(2): 136-41. [CrossRef]

12. Henry MCW, Moss RL. Primary versus delayed wound closure in complicated appendicitis: an international systematic review and metaanalysis. Pediatr Surg Int 2005; 21(8): 625-30. [CrossRef]

13. Bhangu A, Singh P, Lundy J, Bowley DM. Systemic review and metaanalysis of randomized clinical trials comparing primary vs delayed primary skin closure in contaminated and dirty abdominal incisions. JAMA Surg 2013; 148(8): 779-86. [CrossRef]

14. Siribumrungwong B, Noorit P, Wilasrusmee C, Thakkinstian A. A systematic review and meta-analysis of randomised controlled trials of delayed primary wound closure in contaminated abdominal wounds. World J Emerg Surg (WJES); Epub 2020, Mar 31. Available from: https:// www.ncbi.n/m.nih.gov/pmc/articles/PMC4162947/[CrossRef]

15. Tang S, Hu W, Hu L, Zhou J. Primary versus delayed primary incision closure in contaminated abdominal surgery: A meta-analysis. J Surg Res 2019; 239: 22-30. [CrossRef]

\title{
ORIJINAL ÇALIŞMA-ÖZET
}

Turk J Surg 2020; 36 (4): 327-332

\section{İçi boş organ perforasyonu olan hastalarda primer insizyonda gecikmeli primer kapamanın yara iyileşmesi üzerindeki etkilerini analiz eden randomize bir çalışma}

\author{
${ }^{1}$ All Hindistan Tıp Bilimleri Enstitüsü, Cerrahi Disiplinler Anabilim Dalı, Yeni Delhi, Hindistan \\ 2 Nil Ratan Sircar Tıp Fakültesi ve Hastanesi, Cerrahi Kliniği, Kalküta, Hindistan \\ ${ }^{3}$ Medica Super Özel Hastanesi, Genel Cerrahi Kliniği, Kalküta, Hindistan \\ ${ }^{4}$ All Hindistan Tıp Bilimleri Enstitüsü, Biyoistatistik Anabilim Dalı, Yeni Delhi, Hindistan
}

\section{ÖZET}

Giriş ve Amaç: Ciltte, ertelenen primer kapanmanın (EPK), içi boş organ perforasyonuna bağlı peritonit nedeniyle ameliyat edilen hastalarda yüzeysel cerrahi alan enfeksiyonunu (YCAE) azalttığı öne sürülmüştür, ancak bu konuda bir fikir birliği yoktur. Bu çalışmanın amacı; YCAE, fasiyal ayrılma ve hastanede kalış süresi (HKS) açısından primer kapama (PK) ve EPK sonuçlarını karşılaştırmaktı.

Gereç ve Yöntem: Perforasyon peritoniti nedeniyle acil cerrahi müdahale gerçekleştirilen 60 hasta PK $(n=30)$ ve EPK $(n=30)$ olarak randomize edildi. EPK grubundaki hastaların insizyonu, yaranın klinik olarak kapama için uygun olduğu düşünüldüğü takdirde, ameliyattan dört veya daha fazla gün sonra kapatıldı. PC grubundaki hastalarda, insizyon ameliyat sırasında kapatıldı.

Bulgular: YCAE insidansı EPK grubunda $(\% 7,4)$ PK'ye $(\% 42,9)$ kıyasla anlamlı olarak daha düşüktü $(p=0,004)$. Bununla birlikte, EPK'nin medyan süresi 10. gün idi, yani bu yaraların klinik olarak kapanmaya uygun hale gelmesi için belirgin bir zaman gerekiyordu. Fasiyal ayrılma insidansı iki grup arasında benzer seviyedeydi ( $p=0,67)$. Hastanede kalış süresi (HKS) EPK grubunda 13,8 gün iken PK'de 13,5 gündü; bu fark anlamlı değildi $(p=0,825)$.

Sonuç: Cerrahi kesinin EPK'si, YCAE'nin azalmasına neden oldu. Bununla birlikte, bu yaraların EPK'ye uygun hale gelmesi belirgin bir zaman aldığından ve bu durum da EPK'nin PK'ye göre gerçek bir avantajı olup olmadığını sorgulanır kıldığından, bu durum hastanede kalış süresinde azalmaya dönüşmedi.

Anahtar Kelimeler: Organ perforasyonu, cerrahi alan enfeksiyonu, peritonit, yara enfeksiyonu, ertelenen primer kapanma

Doi: $10.47717 /$ turkjsurg.2020.4882 